\title{
Assessment of 2010 air quality in two alpine valleys from modelling: weather type and emission scenarios
}

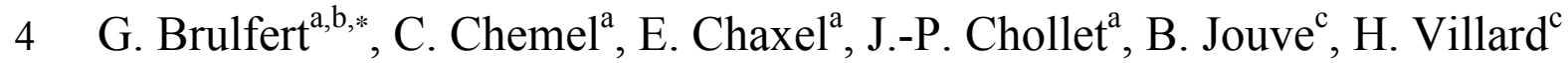

${ }^{\mathrm{a}}$ Laboratory of Geophysical and Industrial Fluid Flows (University J. Fourier, CNRS, INP Grenoble), BP 53, 38041 Grenoble cedex, France

$8{ }^{\mathrm{b}}$ Waterloo Centre for Atmospheric Sciences, University of Waterloo, 200 University Avenue West, Waterloo, Ont., N2L 3G1, Canada

c Air de l'Ain et des Pays de Savoie, Air Quality Agency, 430 rue de la Belle Eau, Z.I. Landiers Nord, 73000 Chambéry, France

\section{Abstract}

Alpine valleys are sensitive to anthropogenic emissions. Local atmospheric dynamics are a key factor that may lead to an accumulation of pollutants in the bottom of the Chamonix and Maurienne valleys. Assessment of 2010 pollutant concentrations

20 variability needs to take these specificities into account. A meteorological data classification is combined with different emission scenarios in order to run an air quality model. Using simulations of representative scenarios rather than complete years allows for a fine spatial and temporal representation of local atmospheric dynamics and gives

24 access to detailed chemical breakdowns. Results demonstrate the variability of primary and secondary species due to emissions and the predominance of local effects on pollutant concentrations.

28 Keywords: air quality modelling; air pollution; alpine valleys; emission scenarios; meteorological classification.

\section{Introduction}

Narrow valleys in mountainous environments are very peculiar areas when it comes to air quality. Emission sources are generally concentrated close to the valley floor, with

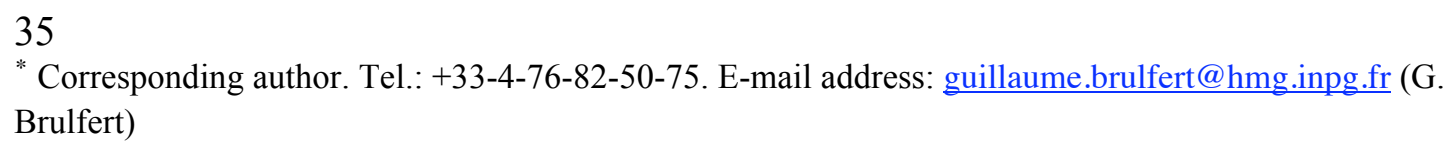


36 sources including transportation networks, towns, and a few industrial plants (Brulfert et al., 2005a).

Following a serious accident in the Mont Blanc tunnel on March 24, 1999, international traffic between France and Italy through the Chamonix valley in France,

40 was stopped. The heavy-duty traffic (about 2130 trucks per day) was transferred to the Maurienne valley in France (up to 4250 trucks per day). Traffic data are made available by the Departmental Directorates of Public Works of Savoie and Haute-Savoie and by the authorities (SFTRF and ATMB) in charge of highways and tunnels in these two

44 valleys.

The Pollution of Alpine Valleys (POVA) program was launched in 2000. The main objectives of the POVA program are: (i) to characterize the pollution sources and evaluate the air quality in both valleys before and after the reopening of the tunnel to

48 heavy-duty traffic, and (ii) to use numerical modelling to derive relationships between atmospheric emissions, pollution events, and atmospheric dynamics. The program includes several field campaigns associated with 3D modelling in order to study the impact of traffic and local development scenarios on air quality in both valleys. The

52 climatology in these valleys is unique, with the sun's heat inducing mountain and valley breezes (particularly in summer) and strong temperature inversions (especially in winter) (Brulfert, 2004; Brulfert et al., 2005b; Chemel and Chollet, 2006, Chaxel et al., 2005).

A first step to 2010 air quality assessment is to identify the climate conditions that

56 may lead to significant levels of pollution. Several studies give a classification of wind field patterns in specific areas for atmospheric dynamics investigations (e.g. Benichou, 1995; Berman et al., 1995; Kaufmann and Weber, 1996; Kaufmann and Whiteman, 1999) and for air quality applications (e.g. Mckendry, 1994; Pryor et al., 1995; Kim

60 Oanh et al., 2005). Most of these classifications are based on the following approach: (i) 
identification of the synoptic patterns at the regional scale, and (ii) analysis of air pollution characteristics associated with each pattern.

In mountainous regions, specific features such as inversion layers and valley breezes

64 are generally not considered when building a meteorological classification (with one notable exception being that Nanni et al. (2004), in a short communication, took into account temperature gradient). Nevertheless, the local atmospheric dynamics is essential for air pollutant concentration (Brulfert et al., 2005b). Consequently, a weather classification has been specifically developed for deep and narrow alpine valleys, taking into account gas and PM10 (particulate matter up to 10 microns in size) concentration variability. The meteorological classification has been drawn up starting from the local scale, which uses ground level stations, to the synoptic scale described by soundings.

72 Then, weather patterns are combined with emissions scenarios (i) to study the variability of $\mathrm{NO}_{\mathrm{x}}, \mathrm{PM10}$ and $\mathrm{O}_{3}$ concentrations due to emissions and (ii) to assess initial projections of air quality in 2010 .

\section{2. Description of valleys}

The Chamonix valley (see Figure 1 for a general view of the domain) is $23-\mathrm{km}$ long with NE-SW orientation and centred on $45.92^{\circ} \mathrm{N}, 6.87^{\circ} \mathrm{E}$, approximately $200 \mathrm{~km}$ from Lyon (France), $80 \mathrm{~km}$ from Geneva (Switzerland) and $100 \mathrm{~km}$ from Torino (Italy).The valley floor stands at $1000 \mathrm{~m}$ above sea level (a.s.l.) on average, and is surrounded by high mountains culminating at the Mont Blanc peak (4810 m a.s.1.). Two detailed maps of Chamonix valley are presented in Figure 1 and 2, page 2343-2344, in Brulfert et al.

84 (2005b). There are no industries or waste incinerators inside the valley. The main anthropogenic emission sources are road traffic, residential heating (mostly with fuel and wood burning) and some agricultural activities. The resident population is about 12000 , but tourist activities bring many more people into the valley: on average 100000 persons 
88 per day in summer and about 5 million overnight stays per year (INSEE, data from 1999 census).There is only one main road crossing the valley, although secondary roads spread over all of the valley floor and the lower slopes.

The Maurienne valley is a typical arc-shaped alpine valley located along the border

92 between France and Italy (see Figure 1 for a general view of the domain). The valley is five times as long as the Chamonix. The global orientation of the valley is roughly W-E. A detailed map of Maurienne valley is presented in Figure 1, page 234, in Brulfert et al. (2005a). The centre of the area $\left(45.33^{\circ} \mathrm{N}, 6.6^{\circ} \mathrm{E}\right)$ is approximately $150-\mathrm{km}$ from Lyon

96 (France) and Geneva (Switzerland) and 100-km from Torino (Italy).

Sixty-three municipalities lie in the valley from Aiton to the Iseran pass, with 42000 inhabitants (census provided by INSEE, 1999). A large part of the population lives in the bottom of the valley, where most of the commercial and industrial activities (and main

100 roads) are located. About 1300 people work in the metallurgical industry (mainly aluminium industries) and more than 300 in chemical industries. The road network is extensive, as a result of some twenty ski resorts and the connection to Italy via the Fréjus tunnel. One year after the closing of the Mont Blanc tunnel in 1999, road traffic had

104 doubled to 8000 vehicles per day, including 5000 heavy duty vehicles.

\section{Day to day weather pattern classification}

\subsection{Weather pattern determination}

Climatology studies of alpine valleys for the purpose of air quality studies must account for local phenomena that are specific to mountainous terrain and are likely to

112 contribute to significant levels of pollution during the daytime and at night. This is due to significant amounts of anthropogenic emissions in the bottoms of valleys, as well as valley breezes, which facilitate the accumulation of pollutants in the bottom of valley. Wind reversals for these two valleys have been documented by observations of the 
116 daytime boundary layer (Chemel and Chollet, 2006). Temperature inversions (occurring frequently throughout the year but especially long-lasting in winter) trap emissions near the pollutant sources and increase concentrations of primary pollutants (e. g. Anquetin et al., 1999). Nevertheless, synoptic circulations also have to be considered since

120 channelling effects will transport the chemical species along the valley.

The classification is based on differentiating between situations dominated by processes local to the valley and situations dominated by synoptic circulations. If a local

124 weather pattern is not observed, the classification turns to a synoptic criterion. Large scale dynamics are documented with soundings from Lyon Satolas Saint Exupery airport $\left(45.73^{\circ} \mathrm{N}, 5.08^{\circ} \mathrm{E}, 235 \mathrm{~m}\right.$. a.s.1.) and from Payerne $\left(46.82^{\circ} \mathrm{N} ; 6.95^{\circ} \mathrm{E} ; 490 \mathrm{~m}\right.$ a.s.1.) and by a combination of ground monitoring station datasets in valleys (wind, humidity and

128 temperature at two stations). These soundings are made less than $200 \mathrm{~km}$ from Chamonix and Maurienne valleys and are representative of high altitude conditions. Payerne soundings have been used instead of Lyon Satolas for so-called "Foehn events" because of north east winds prevailing in these conditions (and shelter effects from the mountain 132 ridge between Chamonix and Lyon).

The data analysis enables us to highlight 5 major weather patterns. The aim of this classification is air quality modelling of 2010 by a limited number of scenarios. But, these local and synoptic patterns are representative of the annual climatology for the 136 purpose of air quality modelling.

The classification period extends from $1 / 1 / 2001$ to $31 / 12 / 2004$. Criteria used to draw up the classification are mentioned hereafter. The screening of an episode against pattern criteria proceeds from local to regional scales. The 5 weather patterns have been

140 identified as: thermally driven $(T)$, stable $(S)$, Foehn $(F)$, west regime $(W)$ and east regime $(E)$. 


\section{Thermally driven pattern (T):}

Winds develop due to thermal gradients from solar heat: down-valley wind at night and up-valley wind during the day. Stations located at the bottom of the valley are used to compare wind direction with the main direction of the valley, provided that the wind's

148 force remains moderate. Indicators for this weather pattern (Table 1) are calculated each day using hourly data from stations located at the bottoms of the two valleys (one station per valley). The average wind speed and direction at night and during the day are considered at different times from one valley to the other because of differences in valley

152 morphology. A day is assigned to the thermally driven pattern $(T)$ if the four indicators comply with the criteria in Table 1 .

\section{Stable pattern (S):}

The atmosphere in deep valleys may remain stable for a long time, especially in winter. Inversions prevent vertical mixing from developing, and pollutants may remain trapped within the valley. A representative temperature gradient is calculated between a

160 station located at the bottom of the valley and a station located at a higher altitude. Meteorological ground monitoring stations that are currently in use are Le Bois $d u$ Bouchet $\left(45.92956^{\circ} \mathrm{N}, 6.87767^{\circ} \mathrm{E}, 1042 \mathrm{~m}\right.$ a.s.1.) and Mont d'Arbois $\left(45.85941^{\circ} \mathrm{N}\right.$, $6.66358^{\circ} \mathrm{E}, 1833 \mathrm{~m}$ a.s.1.) in the Chamonix valley, and Sainte-Marie-de-Cuines

$164\left(45.34025^{\circ} \mathrm{N}, 6.30363^{\circ} \mathrm{E}, 460 \mathrm{~m}\right.$ a.s.1.) and Méribel $\left(45.37357^{\circ} \mathrm{N}, 6.5859^{\circ} \mathrm{E}, 2040 \mathrm{~m}\right.$ a.s.1.) in the Maurienne valley. The temperature gradient is calculated from the difference between the daily maximum absolute temperature value at each measurement site. Although the gradient is not taken along a vertical line and the temperature is measured

168 at ground level, it is observed to be an indicator of the stability of the low atmosphere. Figure 2 describes the evolution of the temperature gradient in valleys. The temperature gradient is observed to be positive in winter and demonstrates the stability of the 
atmosphere, and may also show an inversion layer between the two stations. A day is

172 assigned to the stable pattern $(S)$ for the valley under consideration if the temperature gradient is greater than $-0.3{ }^{\circ} \mathrm{C}$ per $100 \mathrm{~m}$, which corresponds to a subadiabatic temperature gradient.

\section{Foehn pattern (F):}

Foehn is a pattern driven by a combination of local and synoptic conditions. Foehn is not often observed because it corresponds to a very particular situation coupling local

180 and synoptic conditions. The wind comes from the south but blows down to the bottom of the valley, drying the air out. To detect days with Foehn events, humidity is considered at Le Bois du Bouchet in the Chamonix valley and Saint-Marie-de-Cuines in the Maurienne valley: a quick and significant change in humidity is expected. Synoptic

184 wind speed and direction are also essential. In Foehn conditions, prevailing synoptic wind undergoes channelling effects. Since the Lyon sounding may be influenced by the Rhône valley as soon as marine air intrusion penetrates the land, midday soundings (at $500 \mathrm{hPa}$ ) at Payerne have been found to be more representative.

188 A day is assigned to the Foehn pattern $(F)$ provided that $(i)$ relative humidity in the valley is less than $60 \%$ for at least 2 hours and (ii) the wind at midday from the Payerne sounding (at $500 \mathrm{hPa}$ ) comes from the south (direction from $112.5^{\circ}$ to $247.5^{\circ}$ ). Because of specificities in topography, Foehn blows from the north (direction from $337.5^{\circ}$ to

$19222.5^{\circ}$ ) in the Chamonix valley. This wind originates from the lower point of the French / Italian border: the Giant pass, at $3365 \mathrm{~m}$ a.s.1. This pass is oriented south-east, so it channels the wind flow through the Mer de glace glacier down to the valley entering downtown Chamonix from north. 
A day is considered to be in the west regime pattern $(W)$ if the wind direction from the

200 Lyon sounding (500hPa) at midday ranges from 202.5 to $337.5^{\circ}$ (westerly wind). When modelling air quality, this west regime type is based on wind conditions only, unlike classifications more classically used in weather forecasts.

\section{East regime pattern (E):}

A day is considered to follow the east regime pattern $(E)$ if the wind direction from the Lyon Satolas sounding (500hPa) at midday ranges from 22.5 to $157.5^{\circ}$ (easterly 208 wind).

\subsection{Occurrence of patterns throughout the year}

212 Datasets for each day from 2001 to 2004 are compared to criteria in section 3.1 in the following order: $(T)$ thermally driven, $(S)$ stable, $(F)$ Foehn, $(W)$ west regime and $(E)$ east regime. The pattern is indeterminate (I) if data collected for the day do not correspond to any of the class criteria.

216 The yearly distribution of the weather patterns (Figure 3) shows little change from year to year, which suggests that the classification is appropriate for these valleys. The number of days which are not included in one of the 5 patterns is small: $4 \%$ and $7 \%$ indeterminate, and 2\% and 9\% unavailable data in the Chamonix and Maurienne valleys,

220 respectively. Figure 4 shows the monthly distribution of the weather patterns in the two valleys, averaged from 2001 to 2004. The stable pattern $(S)$ is predominant in the winter and thermally driven pattern $(T)$ is predominant in the summer in both valleys, though stable patterns $(S)$ are occasionally observed in summer.

\subsection{Selection of weather pattern episodes}

Due to the spatial and temporal resolution of the different models use for simulation

228 (see section 5. and Brulfert et al., 2005b), time needed to perform computations for a full year is too long. Therefore, the year is simplified to a series of episodes corresponding to 
the 5 patterns defined above. Several episodes have been selected that correspond to the different patterns, and these episodes are summarized in Table 2. Periods from the POVA

232 field campaigns were considered whenever possible. Thermally driven (T), stable (S) and Foehn $(F)$ patterns correspond to days of the POVA intensive observation periods and take advantage of the validation procedure for the simulations. For the two other patterns, episodes are selected that are the same in both valleys.

\section{Emission scenarios}

Pollution levels are computed from a chemistry and transport model. Thus, emission

240 inventories are needed. The 2010 emission scenarios presented here were suggested by the POVA scientific committee. This committee was formed in collaboration with the local air quality agency, the French Office for Public Works, the French Office for Ecology and the French Agency for Environment and Energy Management. These

244 scenarios seek to determine realistic trends by 2010, with special attention given to heavy duty traffic and domestic heating.

These scenarios were drawn up from realistic emission scenarios used by the numerical model during the POVA program. Brulfert et al. (2005a) detailed the

248 methodology used to draw up the emission inventory in the Maurienne valley. The methodology is similar in the Chamonix valley. Uncertainty on emission inventories is very difficult to quantify but we can compare inventories drawn up with different methodologies. For example, in Brulfert et al. (2005a), two Maurienne valley inventories

252 were drawn up using emissions factors from CORINAIR or OFEFP. Results from the comparison between these two inventories show discrepancies around $35 \%$ for NOx and VOC heating emissions.

In our study, we chose to investigate four emission scenarios based on projections 256 from the 2003 emission inventory: 


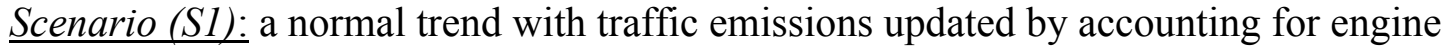
and traffic evolutions (COPERT III, 2001; Bourdeau, 1998) and without any change in the industrial or service sectors. In this scenario, all emissions will decrease in both

260 valleys. These reductions range from $4 \%$ for $\mathrm{SO}_{2}$ to $50 \%$ for $\mathrm{CO}$ in Chamonix valley and from $5 \%$ for $\mathrm{CH}_{4}$ to $28 \%$ for NOx in Maurienne valley (Figure 5).

The two valleys are subject to cross-border traffic with significant contributions from 264 heavy duty traffic. Two hypotheses are considered: (i) a $50 \%$ increase in heavy duty traffic corresponding to an expected increase of transit through the road network only, and (ii) a $50 \%$ decrease when assuming that part of the cross border traffic goes via other means (e.g. Lyon to Torino rail link project). Thus, Scenarios (S2) and (S3) present 268 a modification of $\pm 50 \%$ in heavy-duty traffic:

Scenarios (S2) and (S3): a $50 \%$ increase $(S 2)$ and a $50 \%$ reduction $(S 3)$ of annual heavy-duty traffic within the area of interest (in the base case (S1) this traffic is about 2000 trucks a day).

272 Differences in emissions between Scenario (S3) and Scenario (S2) ((S3) - (S2)) give positives values for all pollutants. Thus, the contribution of a $50 \%$ increase in the number of heavy-duty vehicles represents $1 \%$ of all $\mathrm{CO}, \mathrm{PM}, \mathrm{SO}_{2}, \mathrm{CH}_{4} ; 2 \%$ of the VOC and 17 $\%$ of the NOx in the total 2003 emission inventory. In the Maurienne valley, this

276 represents $1 \%$ of all $\mathrm{CO}, \mathrm{SO}_{2}, \mathrm{CH}_{4}, \mathrm{PM} 10 ; 2 \%$ of the $\mathrm{VOC}$ and $25 \%$ of the $\mathrm{NOx}$ in the total 2003 emission inventory (Figure 5).

The Chamonix and Maurienne valleys were recently supplied with natural gas for 280 domestic heating. Modifications to the concentrations resulting from a complete switch 
from fuel to natural gas will be quantified in Scenario (S4) which is especially devoted to this question.

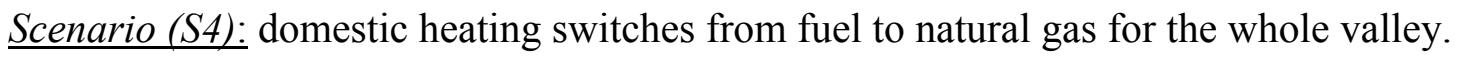

284 This is an idealized situation. Reductions range from $14 \%$ for $\mathrm{VOC}$ to $95 \%$ for $\mathrm{SO}_{2}$ in the Chamonix valley and from $23 \%$ for $\mathrm{VOC}$ to $73 \%$ for $\mathrm{SO}_{2}$ in the Maurienne valley (Figure 5).

288 The main difficulty in defining the emission inventories and scenarios is the compilation and exploitation of primary data. It is not possible to gather all of the primary data for 2003: data are linked to population census and last available data are from 2002 (INSEE, 1999). A uniform evolution of population was considered from year

292 to year. Biogenic emissions are based on 1999 data (inventory of vegetation from satellite observations and meteorological data). Vegetation is reasonably assumed not to significantly change from 1999 to 2010.

Figure 5 shows the evolution of primary pollutant emission from realistic inventories $296(1998,2001,2003)$ and from the 4 scenarios $(S 1),(S 2),(S 3)$ and (S4) in the Chamonix and Maurienne valleys. A sensitive decrease in emissions is observed for the 3 years of inventories and also for all of the scenarios (ranging from 20 to $70 \%$, depending on the pollutant and the valley). From 1998 to 2003, the decrease in emissions is mainly due

300 engine improvements as old cars are replaced with newer models. Pollutant concentrations cannot be directly inferred from emissions because of background concentrations, chemical production, dry deposition and dispersion. This is why a model is needed in order to compute the various concentrations at ground level.

\section{Results from the air quality model}

\subsection{The air quality model}


308 A system of models has been developed to account for atmospheric dynamics and chemistry in alpine valleys and is detailed in Brulfert et al. (2005b). It is based on a hierarchy of atmospheric and chemistry models with several grid nesting levels: ARPS 4.5.2 to resolve the dynamics and TAPOM 1.5.2 for atmospheric chemistry. TAPOM is

312 based on the Regional Atmospheric Chemistry Modelling (RACM) scheme (Stockwell et al., 1997). The VOC chemical speciation is detailed in Brulfert et al. (2005a). This chemistry and transport model can be used to determine a detailed chemical breakdown of primary and secondary pollutants all throughout the year.

316 The finer domains were gridded in the horizontal directions with 300-m x 300-m grid spacings in the Chamonix valley and 1000-m x 1000-m in the Maurienne valley. These finer grids encompass a domain of about $25 \mathrm{~km}$ x $25 \mathrm{~km}$ and $90 \mathrm{~km}$ x $100 \mathrm{~km}$ for the Chamonix and Maurienne valleys, respectively. The typical integration time step is 320 around $1 \mathrm{~s}$ for dynamics and for chemistry. Results from the model have been compared to data in the frame of POVA field campaign (Brulfert et al., 2005b), with satisfactory results.

Numerical simulations with this system of models were combined with emission

324 inventories and a background chemistry corresponding to the year 2010 . The 2010 initial and boundary conditions for chemical species were provided by the CHIMERE model (Bessagnet et al., 2004) with prospective emission reduction compiled under the Cooperative Programme for Monitoring and Evaluation of the Long-range Transmission of

328 Air Pollutants in Europe (EMEP) (Vestreng et al., 2004).

With this configuration of models and by taking advantage of the off-line coupling, simulations of the five weather patterns are first computed and then the four emission scenarios are computed with each weather pattern. Modelling specific episodes rather

332 than a full year allows for a fine spatial and temporal resolution and a detailed chemistry. A description of simulated time periods for all scenarios is presented in Table 2 for the 
Chamonix and Maurienne valleys. It should be noted that a good representation of climatology in complex terrain requires fine spatial and temporal resolution and cannot

336 be modelled at large scale (Drobinski et al., 2005; Martilli et al., 1998). Results from the simulations are presented as 30-minute averaged values for the first vertical level of the air quality model, which has an average thickness of about 35 meters. Averages over a valley are calculated from the first vertical level over the whole domain. Representations

340 of spatial heterogeneity and time evolution maps for the both valleys in 2003 are presented in section 6 of Brulfert et al. (2005b) and in chapters 5 and 6 of Brulfert (2004). Some vertical cross section animations of ozone concentrations are available at http://tel.ccsd.cnrs.fr/docs/00/04/75/50/ANNEX/tel-00007982.ppt (slides 33 to 37).

344 The next analysis will focus on $\mathrm{NO}_{\mathrm{x}}, \mathrm{PM} 10$ and $\mathrm{O}_{3}$. Historically, only these pollutants were present in high concentrations in valleys. Different chemical species such as VOC (Rouvière et al., 2006) are also computed by the model and are expected to be treated in a similar way in future work.

\section{5.2. Thermally driven pattern $(T)$}

Results of the air quality model using emission scenarios with pattern $(T)$ as the weather pattern show a significant decrease in primary pollutant concentrations and an

352 increase in ozone concentration from 2003 to 2010 in every scenario (see Table 3 for both valleys). The decrease in $\mathrm{NO}_{\mathrm{x}}$ and PM10 concentrations is more noticeable for Chamonix downtown (from 28 to 57 \%) than for Saint-Jean-de-Maurienne (from 4 to 30 $\%)$. The lower levels of primary pollutants make titration of NO less efficient, leading to

356 a small increase in ozone concentration in both valleys (from 1 to $2 \%$ ) for all the emission scenarios. These variations in ozone, although weak, are atmospheric dynamics relevant because they reflect some local changes in concentrations which are averaged over the valley. 
360 Scenario (S4), which expects personal heating to change from fuel to natural gas, is the most effective scenario for decreasing primary pollutant concentrations. An increase of $50 \%$ in heavy-duty traffic (S2) leads to a decrease in primary concentrations from 2003 to 2010: the decrease in emissions linked to 2010's cleaner engines compensates

364 for traffic augmentation (COPERT III, 2001; Bourdeau, 1998).

All of the scenarios demonstrate a sensitive reduction in $\mathrm{NO}_{\mathrm{x}}$ concentrations in both valleys. The reduction in PM10 concentration, although less noticeable, is still relevant.

\subsection{Stable pattern (S)}

Results of the 4 emission scenarios with Stable pattern period show a reduction in primary pollutant concentrations and an increase in ozone concentration (see Table 3 for both valleys). For pattern $(S)$, only scenario (S4) (natural gas for personal use in both

372 valleys) leads to a significant decrease in PM10 concentration in urban area. A decrease or an increase in heavy-duty traffic does not change primary pollutant concentrations in urban areas. Stagnant atmospheric conditions and weak horizontal diffusion account for the latter result.

376 In all of the emission scenarios, the $\mathrm{NO}_{\mathrm{x}}$ concentration significantly decreases (by factors ranging from 7 to $28 \%$ ) from rather high values in these two urban areas (59 and 145 ppbv in Chamonix downtown and Saint-Jean-de-Maurienne, respectively). The increase in ozone concentration in the two urban areas is about $15 \%$ and tends to be

380 close to the background level.

\subsection{Foehn pattern $(F)$}

Unlike the two previous patterns, scenario (S1) (natural evolution trend) shows a

384 decrease in primary pollutant concentrations (see Table 3 for both valleys). This reduction is a little bit more significant (by 1 to $7 \%$ ) than for scenario (S2) (increase of $50 \%$ in heavy-duty traffic). So, an increase in heavy-duty traffic in scenario (S1) will not significantly change the concentrations. Once more, with pattern $(F)$, all of the scenarios 
388 lead to a decrease in primary concentrations and an increase in ozone concentration to match background levels because of weak ozone titration by NO.

Foehn is a very specific wind in the Alps and induces different wind flows, which depend on valley morphology. Wind flow during Foehn episodes arrives from the north

392 in the Chamonix valley (see section 3.1.). Consequently, pollutants from the major highway never contribute to pollutant concentrations in Chamonix urban areas. The simulations support these observations: $\mathrm{NO}_{\mathrm{x}}$ and $\mathrm{PM} 10$ concentrations decrease in Chamonix urban area for all scenarios (Table 3).

\subsection{West regime pattern $(W)$}

The maximum concentrations of $\mathrm{NO}_{\mathrm{x}}$ at Chamonix occur with pattern $(W)$ (see Table 3 for both valleys). Westerly wind moves the air mass from the major highway to the 400 urban area. Reduction of PM10 emissions with the four emission scenarios does not show sensitive modification of the concentration in Chamonix urban area and over the valley. This result differs from the Maurienne valley result where scenario (S4) (natural gas personal heating) shows the greatest decrease in PM10 concentration. This latter

404 result can be explained by noting the small proportion of PM10 emissions that are linked to traffic ( $9 \%$ of annual emission) and by the major part of PM10 emissions from industrial plants ( $40 \%$ of annual emission) and from personal heating ( $49 \%$ of annual emission) in the Maurienne valley.

\subsection{East regime pattern (E)}

The most important modifications to concentrations come with scenario (S4) (natural gas personal heating) where we can observe an important decrease in $\mathrm{NO}_{\mathrm{x}}$ concentration

412 in the two valleys and in PM10 concentration in the Maurienne valley (Table 3 for both valleys). As for emission scenarios of pattern $(W)$, we do not observe a change in PM10 concentrations in the Chamonix valley in any of the 4 scenarios. This is due to a low contribution of particulate matter emissions from traffic (see section 5.4.). East regime 
416 pattern induces more effects on concentrations in the Maurienne valley and Saint-Jeande-Maurienne. A large part of the valley's orientation is W-E, and anthropogenic emissions from the east part of the valley are weak.

\section{Year 2010 recovery from the different scenarios}

The results obtained from each weather pattern may be combined to compute yearly average. The yearly averaged concentration, $\boldsymbol{C}_{\boldsymbol{j}}$, of each species $\left(\mathrm{NO}_{\mathrm{x}}, \mathrm{PM} 10\right.$ and O3) is

424 calculated according to

$$
C_{j}=\sum_{i=1}^{5}\left(P_{j i} X_{i}{ }^{\prime}\right.
$$

where $\boldsymbol{P}_{\boldsymbol{j} i}$ is the concentration of chemical species, $\boldsymbol{P}$, for the emission scenario, $\boldsymbol{j}$, and $\boldsymbol{X}_{\boldsymbol{i}}$ is the occurrence of the weather pattern, $\boldsymbol{i}$. Occurrences are calculated from data

428 presented in Figure 3, which represent monthly averages from 2001 to 2004. 'Indeterminate' and 'no data' cases are not considered. A summary is given in Table 4 for both valleys. Merging of patterns $(T)$ and $(S)$ represents $74 \%$ of the yearly period in the Chamonix valley. In the Maurienne valley, pattern $(T)$ represents $44 \%$ of the yearly

432 period $(12.5 \%$ for pattern $(S))$. It shows that local atmospheric dynamics are predominant in such deep and narrow valleys.

Recovered yearly average concentrations are presented in Table 5 for both valleys. All the scenarios demonstrate a decrease in primary pollutants. Scenarios (S3) (reduction of $43650 \%$ of heavy-duty traffic) and (S4) (natural gas personal heating) show the greatest reduction of $\mathrm{NO}_{\mathrm{x}}$ concentration (in the order of $30 \%$ ). The increase or decrease in heavy-duty traffic (scenarios (S2) and (S3), respectively) does not noticeably change PM10 concentrations. The main source of PM10 in both valleys is personal heating and

440 not traffic. In the Chamonix valley, pollutant dispersion is weak around emission sources because of the effects of local atmospheric dynamics. Only minor changes are observed 
on averaged concentrations for the whole valley domains since the number of grid meshes affected is too small to have a notable effect on the average PM10 concentration.

444 Yearly averages (from 1998 to 2005) are computed from data at urban stations of the two valleys, collected by the local air quality agency (http://www.atmorhonealpes.org/site/resultats/donnees/acces_donnees.php), and give a range of concentrations from 37 to 84 ppbv for $\mathrm{NO}_{x}$, from 18 to 28 ppbv for $\mathrm{O}_{3}$, and from 24 to 32

$448 \mu \mathrm{g} \mathrm{m}^{-3}$ for PM10. Yearly averages of $\mathrm{O}_{3}$ and $\mathrm{NO}_{\mathrm{x}}$ concentrations generated from the base case agree with this range of observed values. PM10 seemed to be overestimated by the model, presumably because of uncertainties in the PM10 emission inventory (e.g. wood burning in fireplaces) enhanced by the predominance of stable pattern days.

\section{Conclusions}

The objective of this paper is to assess the impact of different emission trends in two 456 alpine valleys. Air quality is influenced by primary pollutants emitted from road traffic and heating. It is also influenced by secondary pollutants such as ozone, which result from the air mass at the regional scale interacting with emissions from the bottom of the valley. Winter differs from summer in dominant wind regimes (Figure 4) and the

460 modelling takes full account of seasonal variability.

Pollutant dispersion in such deep and narrow valleys depends on atmospheric dynamics, which strongly influenced by local processes specific to complex terrain. A classification has been developed with emphasis on valley-scale criteria while taking into

464 account the influence of synoptic winds. From screening meteorological datasets, five patterns have been defined: thermally driven $(T)$, stable $(S)$, Foehn $(F)$, west regime $(W)$ and east regime (E). With this classification applied to 2001-2004 datasets, a predominance of local patterns $(T)$ and $(S)$ can be observed in the Chamonix and the 468 Maurienne. 
One episode from past years was selected to represent each weather pattern (Table 2), taking advantage of the most documented POVA-intensive observation periods for three of them. By associating the frequency of occurrence of a weather pattern with each of 472 these episodes, a representation of a typical year can be achieved.

Scenarios were defined as corresponding to year 2010: reference scenario (S1) is compared to (i) scenario (S2) with $50 \%$ heavy-duty traffic increase, (ii) scenario (S3) with $50 \%$ heavy-duty traffic decrease, (iii) scenario (S4) with natural gas domestic

476 heating. Although restricted to these 4 emission scenarios, the computations, when combined with the 5 weather patterns, can be used to produce 20 different sets of simulated results.

A significant decrease in primary pollutant concentrations in both valleys is observed 480 for all the scenarios. Scenario (S3) (reduction of $50 \%$ of heavy-duty traffic) leads to the most important decrease of $\mathrm{NO}_{\mathrm{x}}$ concentration in both valleys. Scenario (S4) (natural gas personal heating) also leads to a decrease of $\mathrm{NO}_{\mathrm{x}}$ but to a smaller degree. However, it also provides the most significant decrease of PM10 concentration. PM10 is not

484 influenced by increase or decrease of heavy-duty traffic (scenarios (S2) and (S3), respectively) except in Chamonix urban area, which is less than one kilometre from the major highway. As expected, concentration peaks of primary pollutants can be identified for pattern $(S)$. Pollutant concentrations are still high for pattern $(W)$ with polluted air 488 masses being transported towards the urban area.

Although the concentration of PM10 seems to be overestimated by the model, a measure of the effect of emissions on PM10 pollution can be generated by comparing the concentrations from two scenarios relative to one another. All of the emission scenarios

492 result in an increase in ozone in urban areas in both valleys, reaching values close to regional background concentration. This is due to the reduction in $\mathrm{O}_{3}$ titration by $\mathrm{NO}$, whose concentration decreases with traffic diminishing or natural gas heating. An 
improvement of air quality with regards to primary pollutants is not associated with a

496 decay of secondary pollutants because of the mixing of air within a valley with the regional air masses.

Only two alpine valleys were considered but the results could be extended to similar valleys, with some variations due to differences in topography and orientation, road

500 networks, and inhabitants. Narrow valleys with global orientation differing from $\mathrm{W}$-E could act differently, possibly with higher frequency of either west or east regimes. However, a similar classification would be derived from the measurements.

The four scenarios presented in this present paper have been found to be effective for 504 making reduction policy comparisons. Pollutant concentrations have to be considered, as order of magnitude estimates and the numerical results may not be yet used for regulatory purposes. There is still an amount of uncertainty in emission inventories, especially in domestic heating with a variety of devices including wood burning

508 fireplaces. Emissions from burning wood in these valleys are very difficult to estimate because a lot of houses use their fireplace just for personal pleasure and these data are not taken into account in the government heating census. They presumably contribute significantly to primary pollutants, especially PM10, which requires a significant

512 improvement in organic particulate matter inventory.

Because of the interactions between local and regional air masses, the results from the scenarios depend on hypotheses on global air quality. The 2010 background concentrations were taken for granted. Nevertheless, it is likely to significantly affect air 516 quality within the valley not only for secondary pollutants such as $\mathrm{O}_{3}$ but also for primary pollutants (for instance because of $\mathrm{O}_{3}$ titration by $\mathrm{NO}$ ). Consequently, scenario computations should be run again whenever more accurate air quality background data are available. Of course, the emission inventory scenarios are based on assumptions 
520 decided by the POVA scientific committee (see section 4.), which deserve further considerations beyond the scope of this paper.

\section{Acknowledgements}

524

The research has been supported by Air Rhône Alpes Region, the Agency for Environment and Energy Management (ADEME), Program Primequal 2, the Ministry of Equipment, Transport and Housing (METL) and the Ministry for Ecology and the

528 Durable Development (MEDD). We are grateful to S. Tridon for a large contribution to data treatments and to Amanda Hoff for her comments on this manuscript.

\section{References}

532

Anquetin, S., Guilbaud, C., Chollet, J.-P., 1999. Thermal valley inversion impact on the dispersion of a passive pollutant in a complex mountainous area - Mass, heat and moisture budgets from observations. Atmospheric Environment 33(7), Volume 33, pp. 3953-3959.

Benichou P., 1995. Classification automatique de configurations météorologiques sur l'Europe Occidentale, Monographie No. 8, Météo France, Service central de la communication et de la commercialisation, Paris, $94 \mathrm{pp}$.

Berman, N. S., Boyer D. L., Brazel, A. J, Brazel, S. W., Chen, R.-R., Fernando, H. J. S., Fitch, M. J., 1995. Synoptic classification and physical model experiments to guide field studies in complex terrain. Journal of Applied Meteorology 34, 719-730.

Bessagnet, B., Hodzic, A., Vautard, R., Beekmann, M., Cheinet, S., Honoré, C., Liousse, C., Rouil, L., 2004. Aerosol modeling with CHIMERE - preliminary evaluation at the continental scale. Atmospheric Environment 38, 2803-2817.

Bourdeau B.,1998. Évolution du parc automobile français entre 1970 et 2010 [Convention ADEME 9666014]. Thèse de doctorat: Ingénierie de l'Environnement. 
552 Chambery: Université de Savoie, 389 p. LEN9801. Available at :

http://www.inrets.fr/ur/lte/publications/publications-pdf/Joumard/these_Bourdeau.pdf

Brulfert, G., 2004. Modélisation des circulations atmosphériques pour l'étude de la pollution des vallées alpines. $\mathrm{PhD}$ dissertation, University Joseph Fourier, Grenoble,

$556 \quad$ France, $263 \mathrm{pp}$. Available at

http://tel.ccsd.cnrs.fr/docs/00/04/75/50/PDF/tel-00007982.pdf

Brulfert, G., Chollet, J.-P., Jouve, B., Villard, H., 2005a. Atmospheric emission inventory of the Maurienne valley for an atmospheric numerical model. Science of the $560 \quad$ Total Environment 349, 232-248.

Brulfert, G., Chemel, C., Chaxel, E., Chollet, J.-P., 2005b. Modelling photochemistry in alpine valleys. Atmospheric Chemistry and Physics 5, 1797-1828.

Chaxel, E., Chollet, J.-P., Brulfert, G., Chemel, C., 2005. Production of ozone in Chamonix valley (France). International Journal of Environment and Pollution 24, $568 \quad 201-217$.

Chemel, C., Chollet, J.-P., 2006. Observations of the daytime atmospheric boundary layer in deep alpine valleys. Boundary-Layer Meteorology. In press.

COPERT III, 2001. Leonidas Ntziachristos and Zissis Samaras. Computer programme to calculate emissions from road transport, methodology and emission factors (version 21).

576 Drobinski, P., Bastin, S., Dusek, J., Zangl, G. and Flamant, P.H., 2005. Flow splitting at the bifurcation between two valleys: idealized simulations in comparison with Mesoscale Alpine Programme observations. Meteorology and Atmospheric Physics, DOI 10.1007/s00703-005-0158-3.

INSEE, 1999. Census of the population by the French National Institute of Statistics and 584 Economic Studies. Informations available at http://www.recensement.insee.fr. 
Kaufmann, P., Weber, R. O., 1996. Classification of mesoscale wind fields in the MISTRAL field experiment. Journal of Applied Meteorology 35, 1963-1979.

Kaufmann, P., Whiteman, C. D., 1999. Cluster-analysis classification of wintertime wind patterns in the Grand Canyon region. Journal of Applied Meteorology 38, 1131-1147. 592

Kim Oanh, N. T., Chutimon, P., Ekbordin, W., Supat, W., 2005. Meteorological pattern classification and application for forecasting air pollution episode potential in a mountain-valley area. Atmospheric Environment 39, 1211-1225.

596

Martilli, A., Graziani, G., 1998. Mesoscale circulation across the Alps: preliminary simulation of TRANSALP 1990 observations. Atmospheric Environment 32, No 7, $600 \quad$ pp 1241-1255.

Mckendry, I. G., 1994. Synoptic Circulation and Summertime Ground-Level Ozone Concentrations at Vancouver, British Columbia. Journal of Applied Meteorology 33, $604 \quad 627-641$.

Nanni, A., Brusasca, G., Calori, G., Finardi, S., Tinarelli, G., Zublena, M., Agnesod, G., Pession, G., 2004. Integrated assessment of traffic impact in an Alpine region. Science of the Total Environment 299, 465-471.

Pryor, S. C., Davies, T. D., Hoffer, T. E., Richman, M. B., 1995. The influence of synoptic scale meteorology on transport of urban air to remote locations in the southwestern United States of America. Atmospheric Environment 29, 1609-1618.

Rouvière, A., Brulfert, G., Baussand, P., Chollet, J.P, 2006. Biogenic emissions of 616 terpenes from Chamonix in alpine valleys. Atmospheric Environment, in press.

Stockwell, R., Kirchner, F., Kuhn, M., and Seefeld, S., 1997. A new mechanism for atmospheric chemistry modelling, Journal of Geophysical Research 102(D22), 25 $847-25879$. 
620 Vestreng, V., Adams, M., Goodwin, J., 2004. Inventory review 2004. Emission data reported to CLRTAP and under the NEC Directive, Technical report MSC-W 1/2004, European Environment Agency, Copenhagen, Denmark, 105 pp.

624

\section{Figure captions}

Fig. 1. Overview of a part of the Alps including the POVA program area. The boxes

628 delimit the finest nested domains used for simulations in the Chamonix and the Maurienne valleys.

Fig. 2. Temperature gradient: (a) calculated from Le Bois du Bouchet (1042 m a.s.1.) and

632 Mont d'Arbois (1833m a.s.1.) monitoring stations in the Chamonix valley and (b) calculated from Sainte-Marie-de-Cuines (460 m a.s.1.) and Méribel (2040 m a.s.1.) monitoring stations in the Maurienne valley, from July 2001 to April 2004.

636 Fig. 3. Yearly distribution of weather patterns from 2001 to 2004: (a) in the Chamonix valley and (b) in the Maurienne valley.

Fig. 4. Monthly distribution of weather patterns (averaged from 2001 to 2004): (a) in the

640 Chamonix valley and (b) in the Maurienne valley.

Fig. 5. Emission inventories for years 1998, 2001, 2003 and emission scenarios (S1), (S2), (S3) and (S4) for CO, VOC, $\mathrm{NO}_{\mathrm{x}}, \mathrm{PM}^{\mathrm{N}} \mathrm{C}, \mathrm{SO}_{2}$ and $\mathrm{CH}_{4}$ (ton year ${ }^{-1}$ ): (a) in the 644 Chamonix valley and (b) in the Maurienne valley. 
652 Table 1

Criteria on average wind speed and direction to comply with the thermally driven pattern (T).

\begin{tabular}{l|cccc}
\hline & time period & Maurienne & time period & Chamonix \\
(UTC) & valley & 1.5 ) & valley \\
\hline Average wind speed during the day & from 0900 to 2000 & $1.5-5 \mathrm{~m} \mathrm{~s}^{-1}$ & from 1000 to 1800 & $1-4 \mathrm{~m} \mathrm{~s}^{-1}$ \\
Average wind direction during the day & from 0900 to 2000 & $180-360^{\circ}$ & from 1000 to 1800 & $112.5-292.5^{\circ}$ \\
Average wind speed at night & from 2300 to 0700 & $0-2 \mathrm{~m} \mathrm{~s}^{-1}$ & from 2100 to 0700 & $0-2 \mathrm{~m} \mathrm{~s}^{-1}$ \\
Average wind direction at night & from 2300 to 0700 & $0-180^{\circ}$ & from 2100 to 0700 & $292.5-112.5^{\circ}$ \\
\hline
\end{tabular}
656

660

664

Table 2

Episode typical of each of the 5 weather patterns.

\begin{tabular}{ll}
\hline Stable $(S)$ & from December 15 to 19,2001 in both valleys \\
Thermally driven $(T)$ & from June 25 to July 2,2003 in the Maurienne valley \\
Foehn $(F)$ & from July 4 to 11,2003 in the Chamonix valley \\
West regime $(W)$ & from August 25 to 26,2000 in both valleys \\
East regime $(E)$ & from November 7 to 8,2001 in both valleys \\
\hline 668 &
\end{tabular}

672

676

680 
Table 3

Weather patterns and the 4 emission scenarios. Each table cell indicates (i) on the upper line, the concentration calculated using the 2003 emission inventory, (ii) on the bottom 696 line, the variation from this latter value for scenarios $(S 1)$ / (S2) / (S3) / (S4), respectively.

\begin{tabular}{|c|c|c|c|c|}
\hline weather pattern & & $\mathrm{NO}_{\mathrm{x}}(\mathrm{ppbv})$ & PM10 $\left(\mu \mathrm{g} \mathrm{m}^{-3}\right)$ & $\mathrm{O}_{3}(\mathrm{ppbv})$ \\
\hline \multirow[t]{6}{*}{ thermally driven } & Chamonix & 86 & 24 & 30 \\
\hline & downtown & $-33 \% /-28 \% /-38 \% /-38 \%$ & $-57 \% /-57 \% /-57 \% /-57 \%$ & $+35 \% /+29 \% /+43 \% /+43 \%$ \\
\hline & Average over the & 3 & 10 & 53 \\
\hline & Saint-Jean-de- & 29 & 37 & 40 \\
\hline & Maurienne & $-22 \% /-13 \% /-30 \% /-27 \%$ & $-4 \% /-4 \% /-4 \% /-22 \%$ & $+9 \% /+5 \% /+12 \% /+11 \%$ \\
\hline & Average over the & 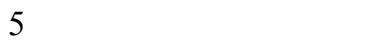 & 13 & 52 \\
\hline \multirow[t]{6}{*}{ stable } & Chamonix & 59 & 141 & 17 \\
\hline & downtown & $-19 \% /-13 \% /-26 \% /-19 \%$ & $-0.4 \% /-0.4 \% /-0.4 \% /-26 \%$ & +9\%/+5\%/+14\%/+9\% \\
\hline & Average over the & 4 & 67 & 41 \\
\hline & Chamonix valley & $-21 \% /-13 \% /-28 \% /-21 \%$ & $-0.1 \% /-0.1 \% /-0.1 \% /-0.1 \%$ & $+1 \% /+0.4 \% /+1 \% /+1 \%$ \\
\hline & Saint-Jean-de- & 145 & 174 & 6 \\
\hline & Maurienne & $-10 \% /-7 \% /-16 \% /-13 \%$ & $-1 \% /-1 \% /-1 \% /-49 \%$ & $+18 \% /+11 \% /+34 \% /+20 \%$ \\
\hline \multirow{6}{*}{ foehn } & Average over the & 3 & 9 & 56 \\
\hline & Chamonix valley & $-38 \% /-34 \% /-42 \% /-42 \%$ & $-0.1 \% /-0.1 \% /-0.1 \% /-0.1 \%$ & $+1 \% /+1 \% /+1 \% /+1 \%$ \\
\hline & Saint-Jean-de- & 46 & 30 & 32 \\
\hline & Maurienne & $-29 \% /-25 \% /-34 \% /-30 \%$ & $-5 \% /-5 \% /-5 \% /-41 \%$ & $+18 \% /+15 \% /+22 \% /+19 \%$ \\
\hline & Average over the & 5 & 11 & 54 \\
\hline & Maurienne valley & $-39 \% /-32 \% /-47 \% /-39 \%$ & $-2 \% /-2 \% /-2 \% /-4 \%$ & $+2 \% /+2 \% /+2 \% /+2 \%$ \\
\hline \multirow[t]{5}{*}{ west regime } & Chamonix & 122 & 59 & 4 \\
\hline & downtown & $-13 \% /-7 \% /-19 \% /-19 \%$ & $-0.2 \% /-0.2 \% /-0.2 \% /-0.2 \%$ & $+16 \% /+8 \% /+27 \% /+27 \%$ \\
\hline & Average over the & 4 & 40 & 43 \\
\hline & Chamonix valley & $-23 \% /-12 \% /-34 \% /-34 \%$ & $-0.1 \% /-0.1 \% /-0.1 \% /-0.1 \%$ & $+1 \% /+0.3 \% /+1 \% /+1 \%$ \\
\hline & Saint-Jean-de- & 78 & 118 & 6 \\
\hline \multirow{3}{*}{ east regime } & Maurienne & $-4 \% /-3 \% /-7 \% /-8 \%$ & $-0.3 \% /-0.3 \% /-0.3 \% /-48 \%$ & $+9 \% /+6 \% /+15 \% /+10 \%$ \\
\hline & Average over the & 6 & 71 & 38 \\
\hline & Maurienne valley & $-19 \% /-11 \% /-29 \% /-19 \%$ & $-0.1 \% /-0.1 \% /-0.1 \% /-3 \%$ & $+1 \% /+1 \% /+2 \% /+1 \%$ \\
\hline
\end{tabular}


Table 4

712

Occurrence of the 5 meteorological patterns for each valley from 2001 to 2004.

\begin{tabular}{lccccc}
\hline & Pattern $(T)$ & Pattern $(S)$ & Pattern $(F)$ & Pattern $(W)$ & Pattern $(E)$ \\
\hline Chamonix valley & 0.592 & 0.146 & 0.076 & 0.136 & 0.050 \\
Maurienne valley & 0.443 & 0.125 & 0.085 & 0.271 & 0.076 \\
\hline
\end{tabular}

716

720

Table 5

724 Yearly averaged concentration recovered from weather patterns and emission scenarios. Each table cell indicates $(i)$ on the upper line, the concentration calculated using the 2003 emission inventory, (ii) on the bottom line, the variation from this latter value for scenarios $(S 1)$ / (S2) / (S3) / (S4).

728

\begin{tabular}{llll}
\hline & \multicolumn{1}{c}{$\mathrm{NO}_{\mathrm{x}}(\mathrm{ppbv})$} & \multicolumn{1}{c}{$\mathrm{PM} 10\left(\mathrm{\mu g} \mathrm{m}^{-3}\right)$} & \multicolumn{1}{c}{$\mathrm{O}_{3}(\mathrm{ppbv})$} \\
\hline Chamonix downtown & 83 & 46 & 18 \\
Average over the & $-28 \% /-22 \% /-33 \% /-32 \%$ & $-18 \% /-18 \% /-18 \% /-30 \%$ & $+28 \% /+23 \% /+34 \% /+34 \%$ \\
Chamonix valley & 3 & 24 & 50 \\
& $-32 \% /-23 \% /-42 \% /-40 \%$ & $-0.4 \% /-0.4 \% /-0.4 \% /-0.4 \%$ & $+1 \% /+0.4 \% /+1 \% /+1 \%$ \\
Saint-Jean-de-Maurienne & 62 & 84 & 24 \\
Average over the & $-15 \% /-10 \% /-22 \% /-18 \%$ & $-2 \% /-1 \% /-2 \% /-38 \%$ & $+13 \% /+8 \% /+20 \% /+14 \%$ \\
Maurienne valley & 8 & 38 & 45 \\
& $-28 \% /-16 \% /-43 \% /-32 \%$ & $-1 \% /-0.4 \% /-1 \% /-5 \%$ & $+2 \% /+1 \% /+3 \% /+2 \%$ \\
\hline
\end{tabular}



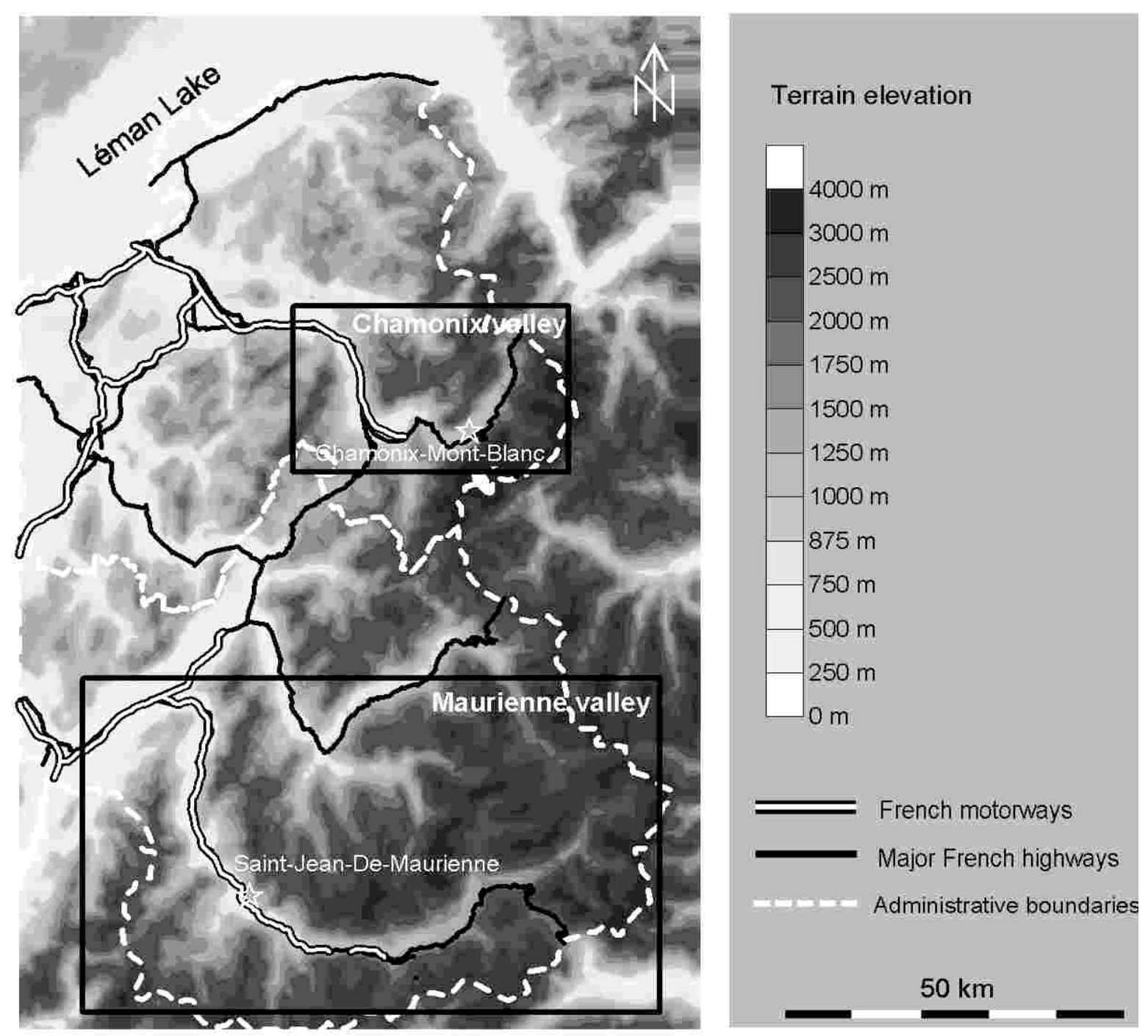

Fig. 1. 
(a)

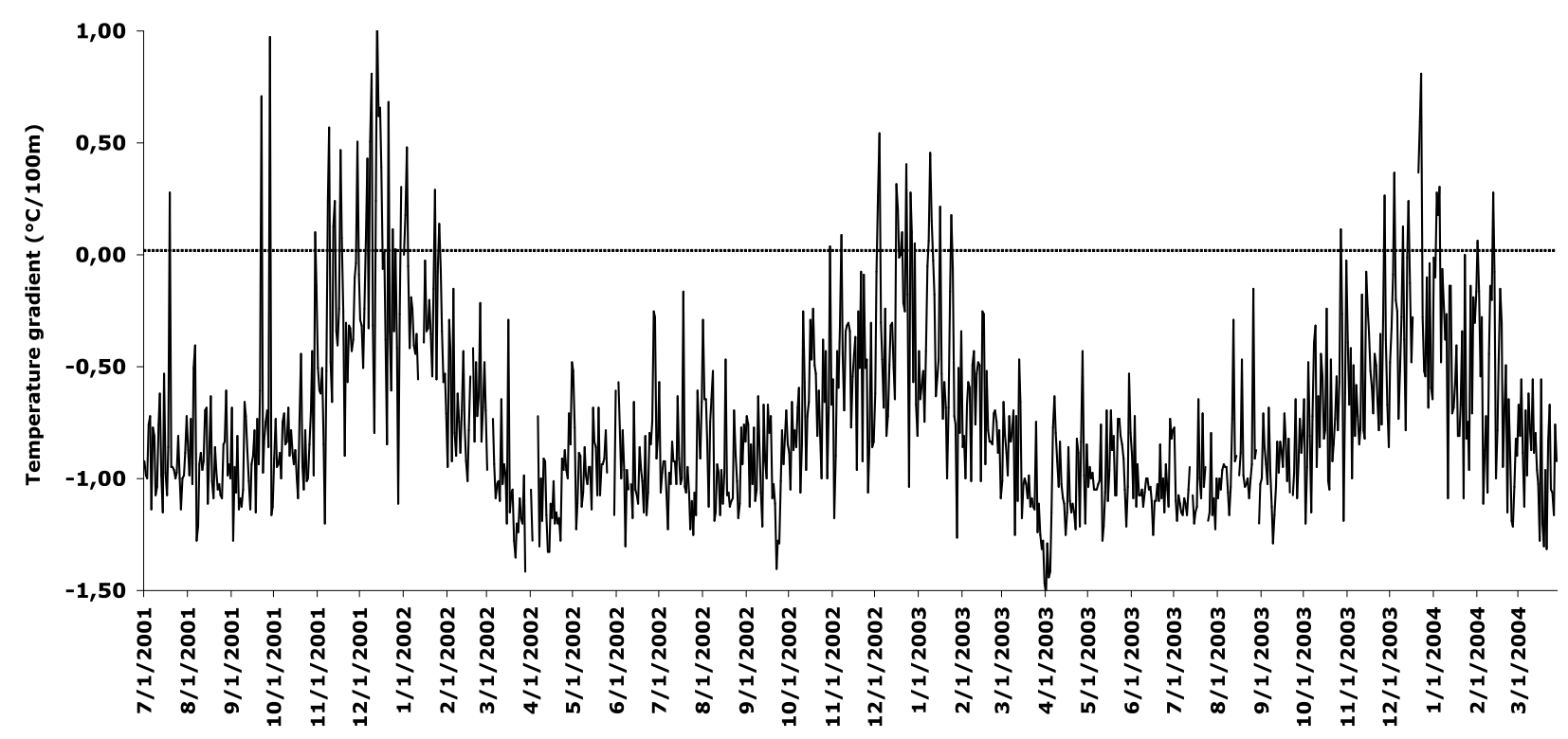

(b)

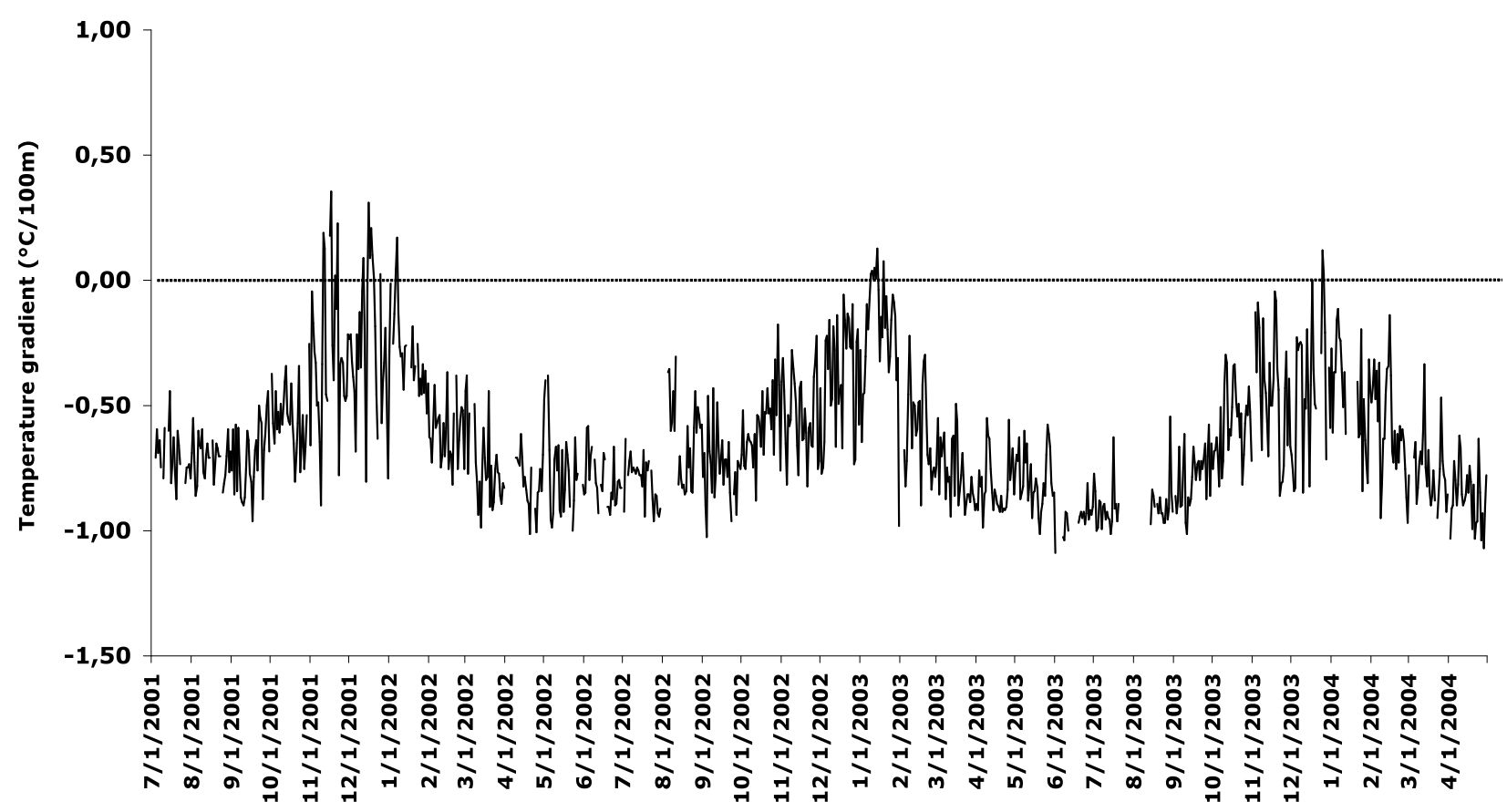

Fig. 2. 
(a)

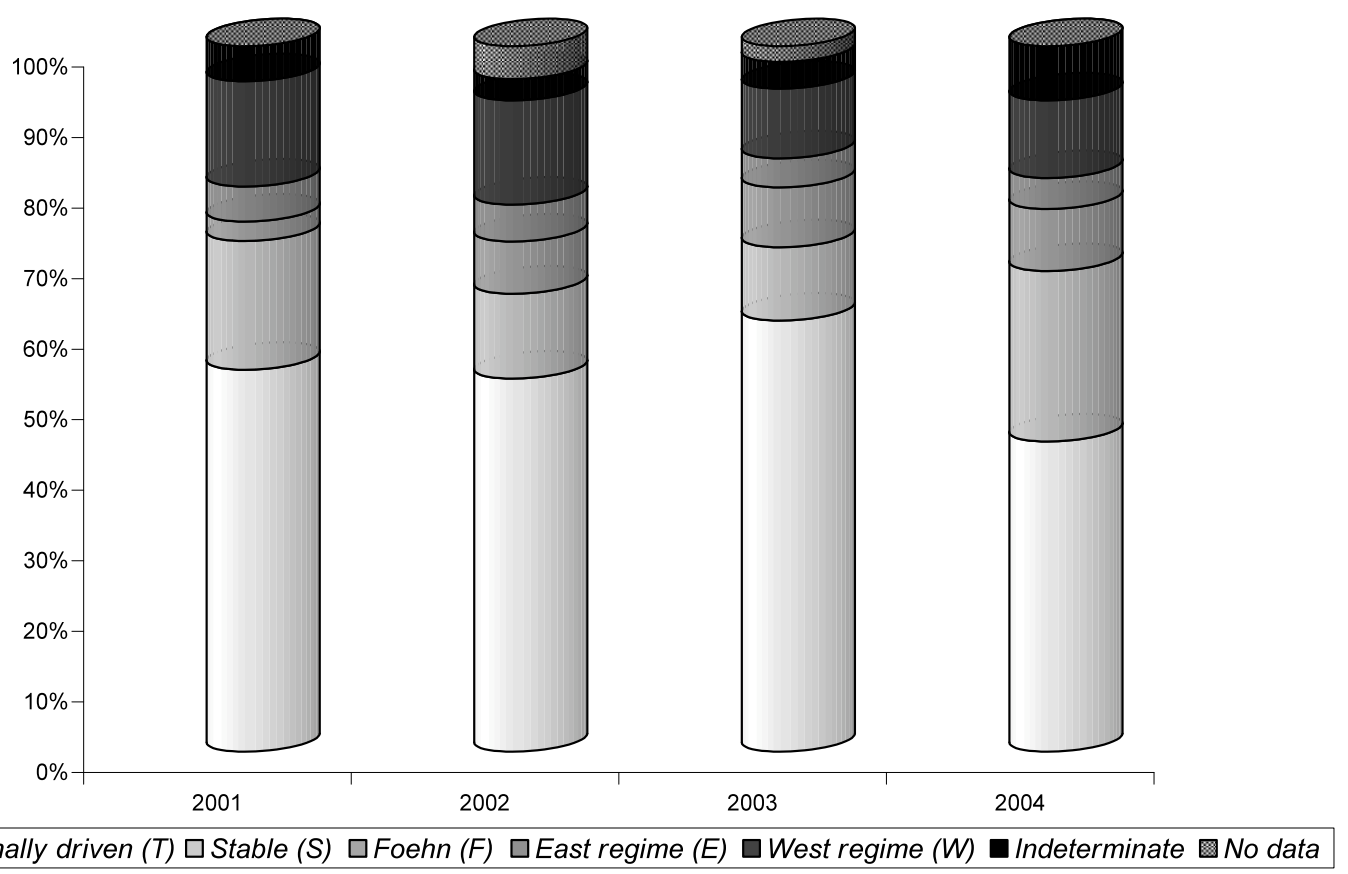

(b)

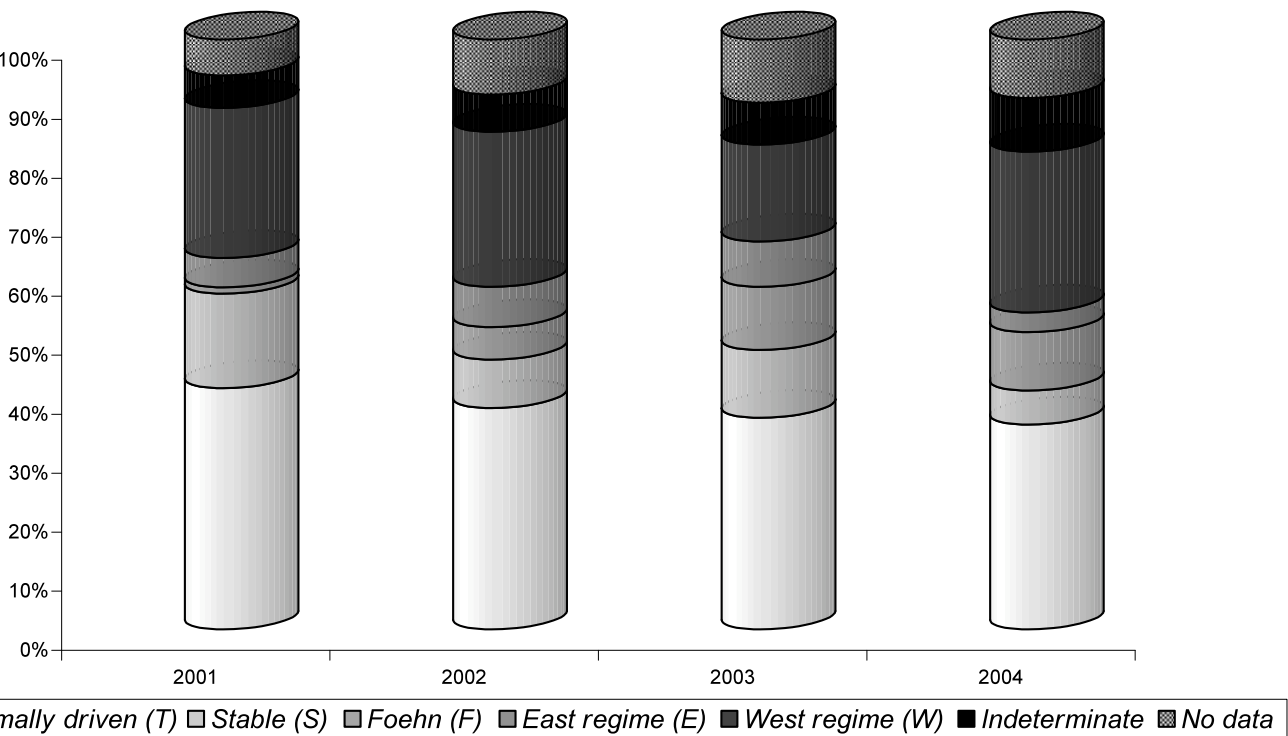

Fig. 3. 
(a)

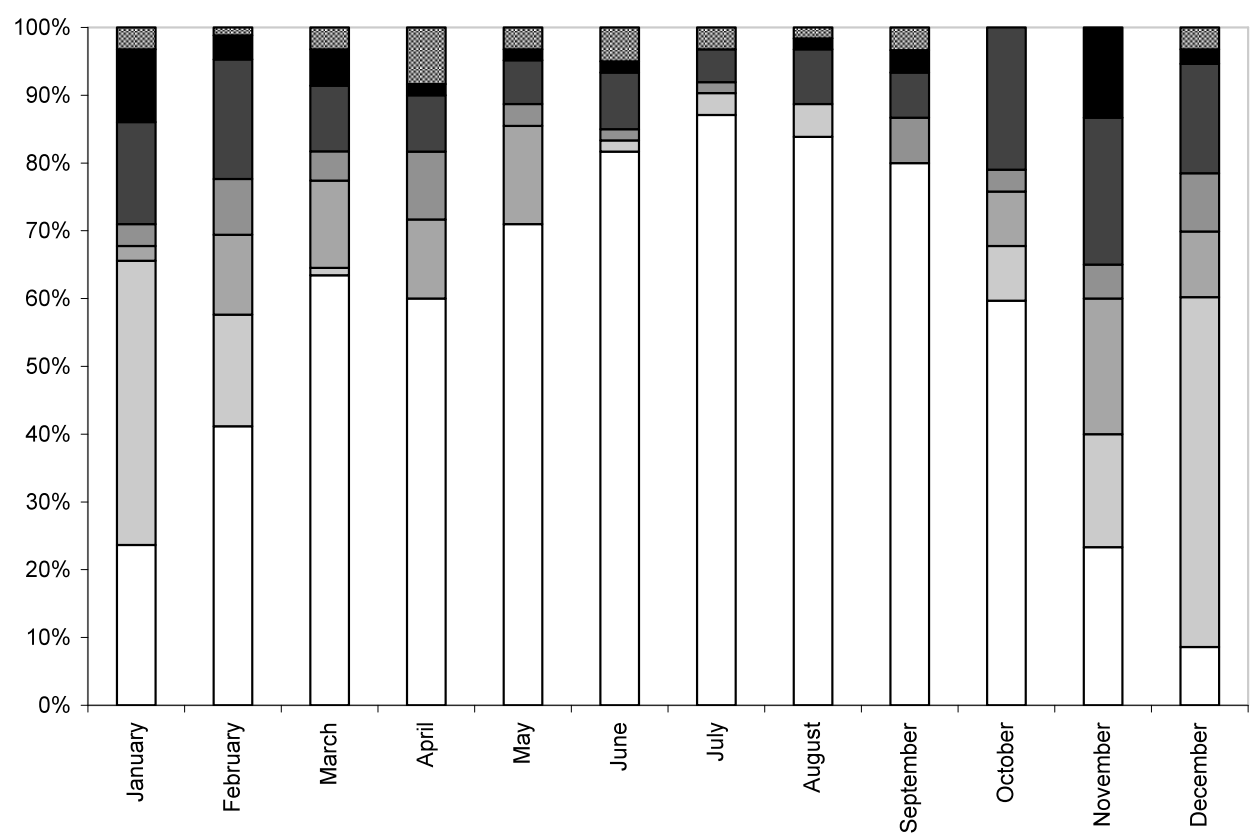

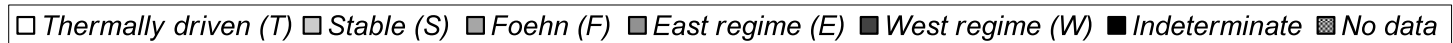

(b)

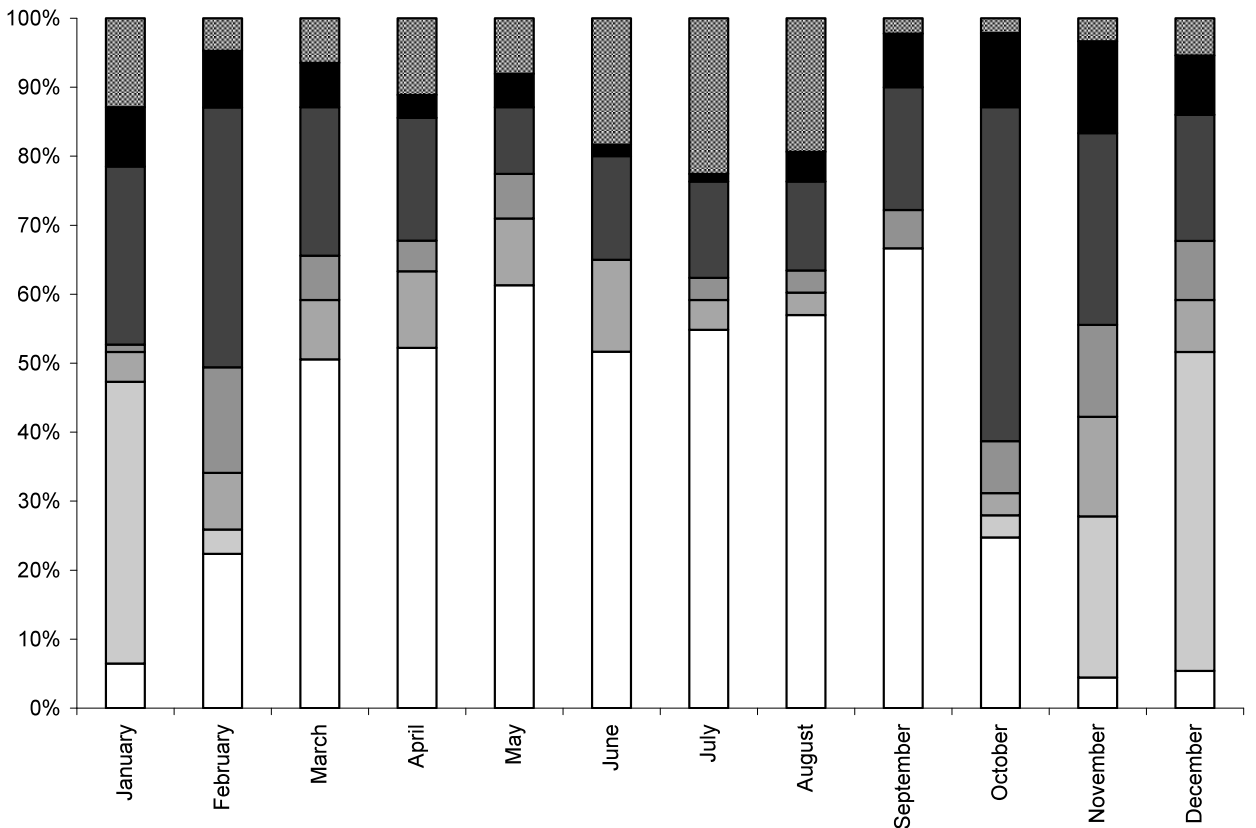

$\square$ Thermally driven (T) $\square$ Stable (S) $\square$ Foehn (F) $\square$ East regime (E) $\square$ West regime (W) $\square$ Indeterminate $⿴ 囗$ No data

Fig. 4. 
(a)

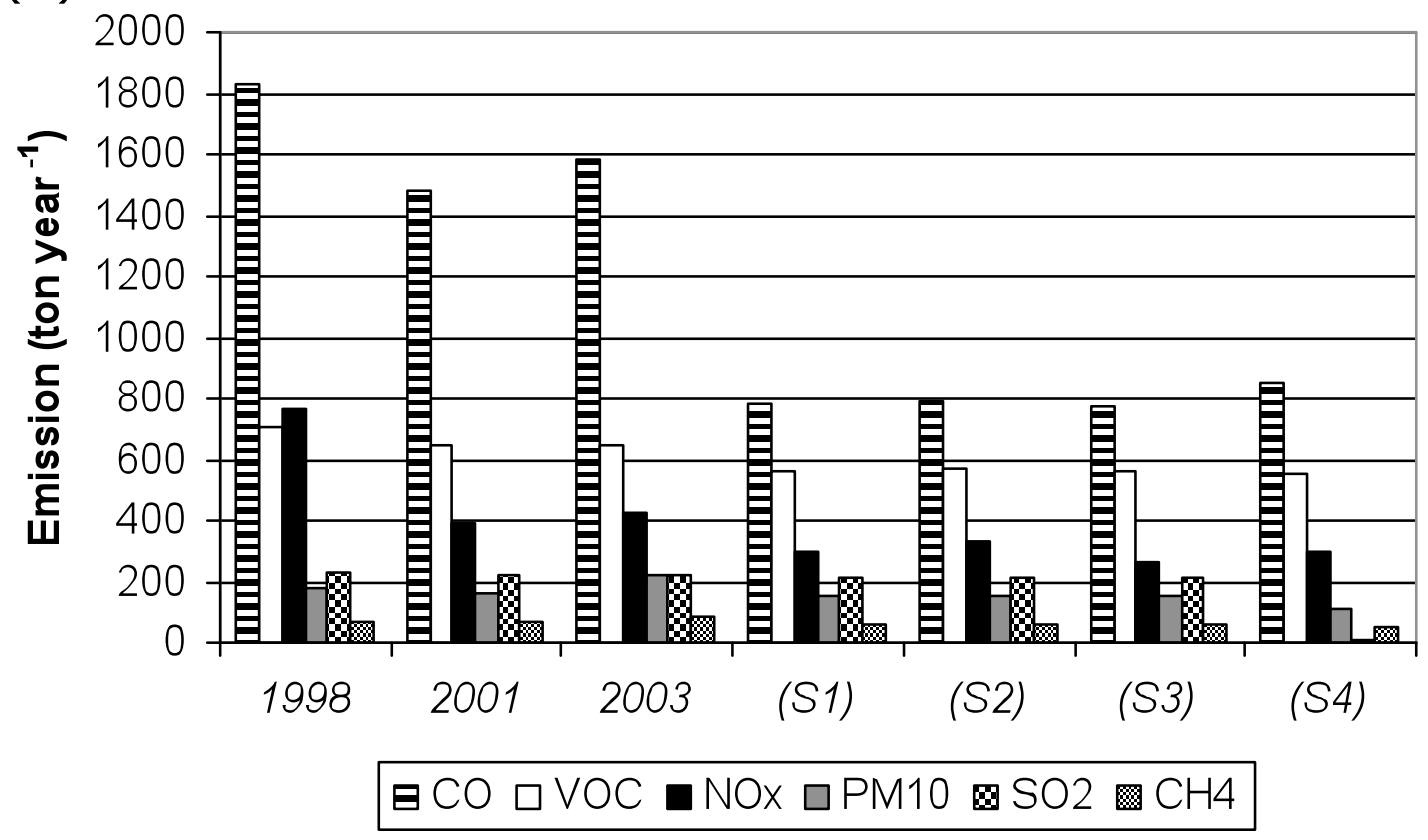

(b)

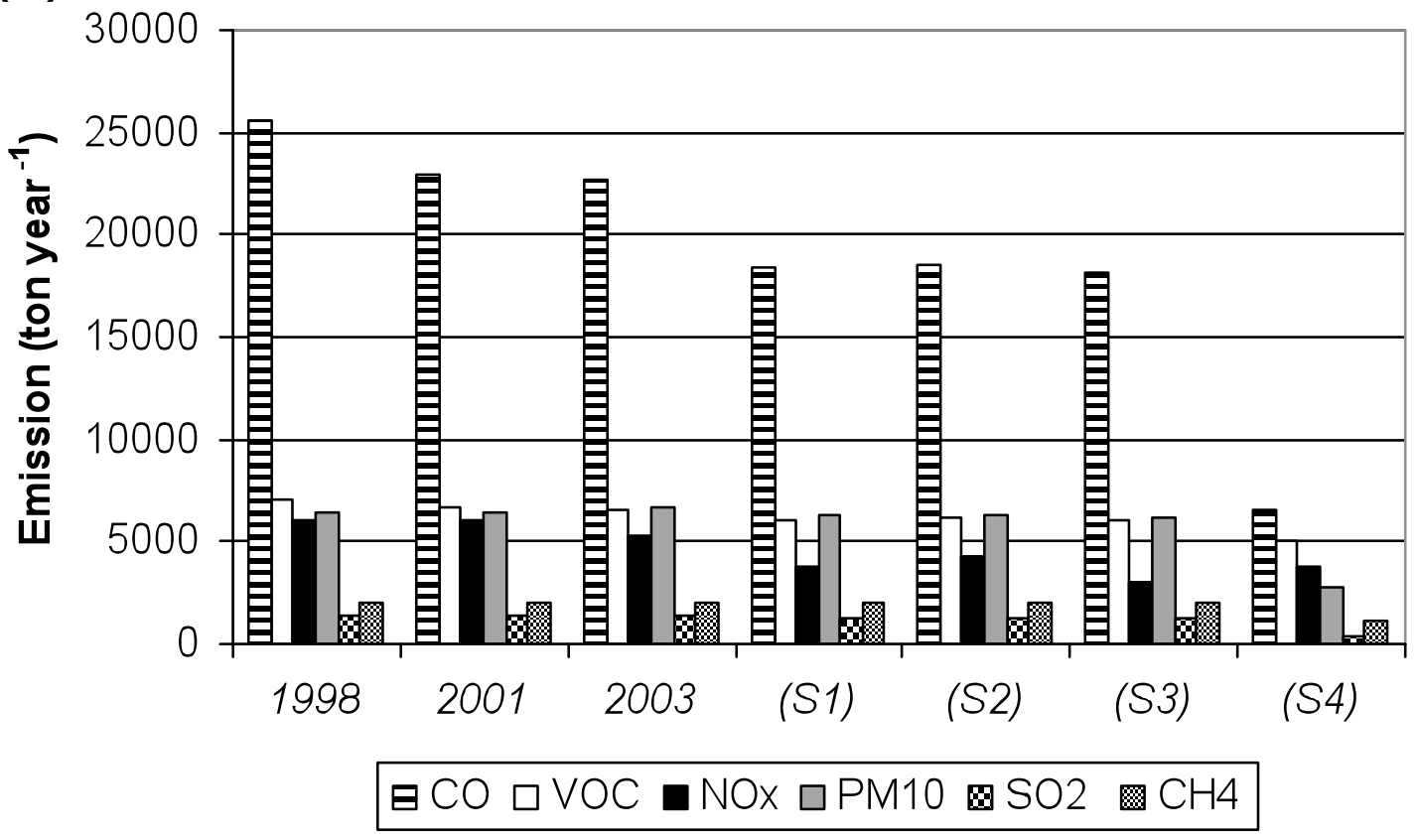

Fig. 5. 